Meta

Journal des traducteurs

Translators' Journal

\title{
Discursive Mediation in Translation: Representation of the Harry Wu topic in the Chinese translations of Living History
}

\section{Hui Wang et Chunshen Zhu}

Volume 54, numéro 4, décembre 2009

URI : https://id.erudit.org/iderudit/038899ar

DOI : https://doi.org/10.7202/038899ar

Aller au sommaire du numéro

Éditeur(s)

Les Presses de l'Université de Montréal

ISSN

0026-0452 (imprimé)

1492-1421 (numérique)

Découvrir la revue

Citer cet article

Wang, H. \& Zhu, C. (2009). Discursive Mediation in Translation: Representation of the Harry Wu topic in the Chinese translations of Living History. Meta, 54(4), 684-703. https://doi.org/10.7202/038899ar

\section{Résumé de l'article}

Le présent article a pour objet les moyens par lesquels se réalise la médiation en traduction : l'inclusion et l'exclusion d'informations à l'étape de sélection, et les déviations discursives à l'étape de présentation. Il traite de l'effet de la médiation en relation avec deux catégories de récepteurs du texte cible, d'un côté, les lecteurs professionnels représentant la censure, et de l'autre, le lectorat ciblé, et les contextes socioculturels qui leur sont spécifiques. Nous plaidons en faveur du fait qu'une recherche sur la traduction, entreprise sous l'angle de la médiation, permet de révéler les luttes de pouvoir sous-jacentes au processus de traduction. La description détaillée de la réalisation textuelle de la médiation, notamment, aide à susciter une prise de conscience à l'égard des moyens divers employés par le producteur du texte pour assurer la médiation du processus de traduction, ceci pour atteindre un compromis entre les intérêts de l'auteur et les préoccupations des lecteurs professionnels et, finalement, publier la traduction. 


\title{
Discursive Mediation in Translation: Representation of the Harry Wu topic in the Chinese translations of Living History
}

\author{
HUI WANG \\ City University of Hong Kong, Hong Kong, China \\ 50008663@student.cityu.edu.hk \\ CHUNSHEN ZHU \\ City University of Hong Kong, Hong Kong, China \\ ctzhu@cityu.edu.hk
}

\begin{abstract}
RÉSUMÉ
Le présent article a pour objet les moyens par lesquels se réalise la médiation en traduction: I'inclusion et l'exclusion d'informations à l'étape de sélection, et les déviations discursives à l'étape de présentation. Il traite de l'effet de la médiation en relation avec deux catégories de récepteurs du texte cible, d'un côté, les lecteurs professionnels représentant la censure, et de l'autre, le lectorat ciblé, et les contextes socioculturels qui leur sont spécifiques. Nous plaidons en faveur du fait qu'une recherche sur la traduction, entreprise sous l'angle de la médiation, permet de révéler les luttes de pouvoir sousjacentes au processus de traduction. La description détaillée de la réalisation textuelle de la médiation, notamment, aide à susciter une prise de conscience à l'égard des moyens divers employés par le producteur du texte pour assurer la médiation du processus de traduction, ceci pour atteindre un compromis entre les intérêts de l'auteur et les préoccupations des lecteurs professionnels et, finalement, publier la traduction.
\end{abstract}

\begin{abstract}
This paper describes how mediation in translation is realized by means of inclusion and exclusion of information at the selection stage and discursive deviations at the presentation stage in the process of target text production. It discusses the effect of mediation in relation to two types of the target text recipients, one is termed professional readers representing the censoring authorities and the other the intended reading public, and their respective socio-cultural backgrounds. Our argument in this paper is that an investigation of translation from the perspective of mediation helps reveal the power struggle underlying the translation process. The detailed description of the textual realization of mediation, in particular, helps create an awareness of the various ways the target text producer may take to mediate the translation process to achieve a compromise between the author's interests and the professional readers' political concerns so as to get the translation published.
\end{abstract}

\section{MOTS-CLÉS/KEYWORDS}

médiation, inclusion et exclusion, déviations discursives, censure

mediation, inclusion and exclusion, discursive deviations, censorship

\section{Introduction}

The year 2003 saw the publication of Hillary Rodham Clinton's autobiography Living History, ${ }^{1}$ which was followed by the publication of a Taiwan Chinese translation 
entitled Huo Chu Li Shi ${ }^{2}$ (Live out/through history, published by China Times), and then a mainland Chinese version Qin Li Li Shi ${ }^{3}$ (First-hand experience of history, published by Yilin Press), all in the same year. Soon after the publication of its translation, the publisher Yilin was accused by the English publisher, Simon \& Schuster, of "a breach of contract." From Simon \& Schuster's news release (2003), ${ }^{4}$ the "breach" can be seen as having two-fold implications: one is technical and professional, for "numerous [unauthorized] changes and deletions" were found in the translation, and the other is political or ideological, as "Senator Clinton's views about China" have been in a way altered. As a result, both the author and the publisher demanded "a faithful and accurate translation."

Judicial implications apart, it is of interest to see how the production of the two Chinese versions can present itself as a case example for the study of the relationship between a translation and the perceived social context in which it is intended to function, an approach informed, among other things, by the so-called functionalist model under the name of skopos theory developed during the 1980s and 1990s. According to this model, the efficacy of a translation should be viewed in the light of its skopos, i.e., its intended social functions, in the target culture rather than its faithfulness to the source text. The skopos of the target text, as Schäffner (2001: 236-237) succinctly summarizes, is "determined by the initiator's, i.e., client's needs," and "largely constrained by the target text user (reader/listener) and his/her situation and cultural background"; whilst the source text is "just one constituent of the commission given to the translator."

Viewed from such a social functional perspective, the situation surrounding the pair of Chinese translations is unique in the following senses:

1) The Yilin version is professed to be largely a rewrite of the China Times version, a practice agreed upon by both Chinese publishers and following the English source text sentence by sentence; 5

2) The rewrite was carried out by the same team of translators, the only difference, it seems, is the order in which their names appear on the title/copyright pages of the two publications;

3) The socio-cultural contexts, in which the two versions are intended to function respectively, are similar in ethnic, cultural and linguistic terms but opposed to each other in political and ideological terms;

4) One of the renderings has been accepted, or at least acquiesced to, by the original author and publisher, whilst the other has been called into question.

One issue therefore stands out in this case: How the impact of an initiator ${ }^{6}$ (or the publisher in our case), as an institutional factor in social functional terms, has been actualized at the level of discourse in the production of a translation, as seen in the Yilin version as against the China Times version and the English original. The present paper is an attempt to examine the matter through a comparative study of the three texts.

In order to highlight the ideological implications of such an institutional factor, some less consequential factors are disregarded. For example, whilst the target language is virtually the same, there are region-specific expressions (analogous to those one may find among 'varieties of English') that may be responsible for dialectal idiosyncrasies between the Chinese versions. This allows us to identify and concentrate on any discrepancies among the three texts that may indicate an ideological inclination. 
Also, given the size of the parallel corpora and the scale of the current investigation, we have to identify a representative element of the texts for closer examination. In this connection, Simon \& Schuster's press release proves to be a very helpful lead, for it pinpoints two particular chapters where changes and deletions that affect the presentation of the author's views about China have been found. One of the chapters is Chapter 22, Women's Rights are Human Rights (p. 298-310). A preliminary comparative reading of the texts shows that deviations in this chapter are related to the following topics: Harry Wu, the Chinese government / officials, and China in general. To keep the study within a manageable yet meaningful scope, we have chosen the topic of Harry Wu as our focus in this project, for, compared with others, it provides a consistent as well as politically sensitive scenario for concentration.

\section{The presentation of the Harry Wu topic in the three texts}

\subsection{The English source text}

The Harry Wu topic is included as a prelude to the main event of the chapter: the US participation in the UN women's conference held in Beijing in 1995. It is presented against the backdrop of the diplomacy between the US and the Chinese government over the former's participation in this conference, with a detailed account of Wu's political background, i.e., his first incarceration in Chinese labor camps as a political prisoner (p. 298) and in particular his second imprisonment in the mainland as a spy. Such a presentation is obviously indicative of the author's concern over the case whilst providing readers with necessary information for relating an individual's fate to a nation's diplomacy in a way intended by the author.

The use of the conjunction although and the modifier valid to describe Wu's arrest in the following line gives an example of the author's position on the matter: "Although he had a valid visa to visit China, he was charged with espionage and thrown in jail to await trial" (p. 298). The presentation about Wu's conviction and eventual release after a sham trial (p. 300) indicate a more explicit ideological stance when the author stated that the Chinese government could not bear more bad publicity (p. 300) over Wu's case.

On the other hand, a close connection is established between $\mathrm{Wu}$ and the US government to illustrate the US concern over China's human rights situation. For example, in the following lines, the use of thrown into limbo and a diplomatic bind stresses the US commitment by linking Wu's case to the US participation in the conference; and that of privately and publicly stresses the extent to which the US has made its commitment known.

(1) Months of meetings and strategy sessions with representatives from the United Nations and other countries were thrown into limbo after Wu's imprisonment.

(2) We were in a diplomatic bind in which Harry Wu's imprisonment and my attendance at the conference were linked.

(3) Our government continued to state privately and publicly that I would not attend if $\mathrm{Mr}$. Wu remained under arrest. (Clinton 2003a: 300)

In the end, with the settlement of Wu's case (i.e., Wu's release from the Chinese prison), the US government, including the White House, State Department, and the President, finally decided that the author should attend the conference held in Beijing. 
The main event of the chapter is then brought in. The final mention of Wu's case associates the topic once again with the women's conference via a positive evaluation of the consequences.

\subsection{The China Times version}

Similar to the English text, the story develops from the protagonist's political background into a diplomatic struggle between the US and the Chinese government over the topical event and the women's conference held in Beijing. The struggle ends in Harry Wu's release and the US final decision to attend the conference. In this process, apart from the listed expressions in the above section, renderings deviating from their English counterparts, as exemplified in italicized expressions in Table 1, are especially notable in revealing the author's ideological stance over the topical event and China's human rights status.

TABLE 1

Deviations in the China Times Version

\begin{tabular}{|c|c|c|}
\hline & Source Text & China Times version and back translation \\
\hline 1 & $\begin{array}{l}\text { Wu [...] as a political prisoner } \\
\text { (p. 298) }\end{array}$ & $\begin{array}{l}\text { 吳弘達 [...] 被打為政治犯。(p. 321) } \\
\text { Wu Hongda [...] was labeled and prosecuted as a } \\
\text { political prisoner. }\end{array}$ \\
\hline 2 & $\begin{array}{l}\text { Overnight, Harry Wu became } \\
\text { widely known, [...]. (p. 298) }\end{array}$ & $\begin{array}{l}\text { 吳弘達在一夕之間家喻戶曉, }[\cdots] \text { 。 (p. 323) } \\
\text { Wu Hongda overnight became a household name, [...]. }\end{array}$ \\
\hline 3 & $\begin{array}{l}\text { We were in a diplomatic bind, } \\
{[\ldots] \text { Harry Wu's imprisonment }} \\
\text { and my attendance at the } \\
\text { conference were linked. (p. } 300)\end{array}$ & $\begin{array}{l}\text { 我們]陷入一種外交牽制, [...] 吳弘達被關和我出席婦女 } \\
\text { 大會 扣在一起。(p. 323) } \\
\text { We sank into a diplomatic bind, [...] Wu Hongda's } \\
\text { imprisonment and my attendance at the women's } \\
\text { conference were now interlocked. }\end{array}$ \\
\hline 4 & $\begin{array}{l}{[\ldots] \text { my attendance might be }} \\
\text { constructed as a tacit approval } \\
\text { of China's record on human } \\
\text { rights. }(p .301)\end{array}$ & $\begin{array}{l}\text { [...] 我的出席可能被解讀為默許中國踐踏人權。 } \\
\text { (p. 323) } \\
\text { [...] my attendance might be interpreted as a tacit } \\
\text { approval of China's tramping on human rights. }\end{array}$ \\
\hline
\end{tabular}

\subsection{The Yilin version}

At the very beginning of the chapter, the tone for the story is set via the author's evaluation on Wu's imprisonment, to the effect that under normal conditions, it would have been overlooked by the American media (possibly because it was assumed to be an internal affair of China). What follows is a brief introduction about the topical event. A link between the topical event and the US preparation for the women's conference is then created when the former acts as the temporal foil for the latter. Finally, Wu's case was settled (i.e., Wu was expelled from China) prior to the conference, and the US decided that the author should make the trip, despite Wu's objection.

Noteworthy is, among other things, the deletion of all such mentions in the English version as listed in Table 1, which is indicative of a distinct ideological position over the topical event and China's human rights status. 


\section{Mediation, selection, and discursive presentation}

According to the functionalist conception, translation is a purposeful social functional activity which involves other parties besides the translator proper. Translation conceived as such extends from textual composition as the translator's personal concern to text publication as a public enterprise in which such other parties are more actively involved. As Fawcett (1995: 189) observes, "the text of a translation in the case of published books is rarely all the translator's own work" as it has to be processed by "a copy editor or other translation reviser" before the final publication. And more often than not, editors and revisers represent the institutional publisher (publication by definition is an institutional act) or the initiator, rather than being disinterested individuals. In the case of Living History, apart from being the initiator, the Taiwan publisher also plays the role of the translator (all translators of the China Times version are editors of China Times), ${ }^{7}$ whilst the mainland publisher takes the sole responsibility for editing and revising. In this connection, we may assume that the deviations displayed respectively in the two Chinese versions from the English original, as illustrated above, can be more meaningfully studied as a result of the publisher's positive discursive mediation than as the consequence of passive negligence of nuances in linguistic form and subject matter.

Mediation as a discursive practice has been a long-standing topic in Critical Discourse Analysis (CDA) and Text Linguistics. At the very beginning of his seminal book, Language in the News, Fowler (1991: 1-4) acknowledges language as "a highly constructive mediator" rather than an innocent verbal instrument, since language intervenes in the construction of social realities, rather than registering them neutrally, by "imposing a structure of values, social and economic in origin on whatever is represented." Taking this as its basic argument, CDA, a "textually oriented discourse analysis" (Fairclough 2003: 2), aims to "investigate critically social inequality as it is expressed, signaled, constituted, legitimized, and so on by language use" (Wodak and Meyer 2001: 10). Such a critical view of language, deeply rooted in Foucault, also underlies the postcolonialist approaches to discourse. In postcolonialist terms, a text as discourse in communication "maps a territory and determines the features of what it charts, thus projecting a domain [or for that matter, a 'world'] to be lived in" or "guides the way we live within this world" (Iser 2006: 172, 175). This projected domain or world is closely linked with "[one's] model of the current communicative situation" as an element of textuality, by which mediation is to be determined as "the extent to which one feeds one's own beliefs and goals into" such a "situation model" (Beaugrande and Dressler 1981: 163). In this light, both text production (i.e., writing) and text processing (i.e., reading), two fundamental components of translating, can be seen as operations of mediation between the existing real world one is living in and the projected discursive world to be lived in. To the existing world, mediation can in fact be a discursive practice of violence, as in Michel Foucault's words, "We must conceive discourse as a violence that we do to things, or, at all events, as a practice we impose on them; and it is in this practice that the events of discourse find the principle of their regularity" (Foucault 1984: 127); according to Iser (2006: 173), "this regularity [of discourse] organizes what 'things' are meant to be."

The presentation of the Harry Wu topic in Living History can thus be seen as creating a situation model into which the author feeds her own beliefs and goals, and 
projecting onto the reader's mind "what 'things' are meant to be" (Iser 2006: 173). Mediation in the presentation of a situation model might be further observed at the level of text composition in terms of the interplay between two operations which are termed as situation monitoring and situation management in Text Linguistics. A text monitors when its "dominant function [...] is to provide a reasonably unmediated account of the situation model," and manages when its "dominant function is to guide the situation in a manner favourable to the text producer's goals," as defined by Beaugrande and Dressler (1981: 163). But the authors go on to point out that:

The borderline between monitoring and managing is extremely fuzzy and can vary according to the views of the individual participants. Indeed, people seem to prefer disguising their managings as monitorings, creating the impression that things are going the desired way in the normal course of events (Beaugrande and Dressler 1981: 163).

This line between the two is fuzzy because, whilst managing is apparently a textual operation of overt imposition, or violation, monitoring is by no means as innocuous as it seems to be. Monitoring operates by the selection, or inclusion in Fairclough's (2003: 135-137) terms, of entities and events for attention in "a reasonably unmediated account" (Beaugrande and Dressler 1981: 163) of the real world we are supposed to be living in. But selection, or inclusion, entails exclusion: whilst some elements are being selected and included in the configuration of a situation before it is projected as a discursive world meant to be lived in, other elements are excluded from such a world. In line with Fowler (1991: 19), selection of events is "an ideological act of interpretation" by the selector, as the events selected "can be seen in a certain light of representation." When it manifests in a discursive form of unmediated monitoring, it becomes a covert, thus more powerful, mode of managing. The selection or inclusion of the $\mathrm{Wu}$ event, of all events in the real world that could be of relevance, in Living History, and the configuration of the event in association with America's attendance at the UN women's conference held in Beijing (another instance of selection), are thus ideologically meaningful. Once selected, any overt signs of mediation, namely, those discursive deviations in the account of the event as we observed in Section 2.1 are but further indications functioning "to guide the situation in a manner favourable to the text producer's goals" (Beaugrande and Dressler 1981: 163).

Mediation, being fundamental to discursive operations, underlies both writing and translating. But translating, as the inter-lingual re-writing of an existing text in another language for another culture, presents a more complicated picture; for in translation, with two languages coming into contact, two systems of values are brought into contest, or even conflict.

In theory, an author can presumably have a free hand in selecting any entity for presentation, in deciding upon its occurrence frequency and its discursive configuration, and in opting for a mode of textualization that either monitors or manages the situation in bringing its constituent entities or events into a coherent interplay. But such freedom is not absolute; instead, it is governed, among other factors, by the social purpose or function, or the skopos (which, incidentally, should not be confined to the study of translation), of the text. For a translation producer, the situation model has been given in the source text, and has been, in its own socio-cultural milieu, deemed appropriate, desirable or effective, as "an ideological act of interpretation" 
(Fowler 1991: 19) by all parties involved in its production. It is "an offer of information," according to Nord (2001: 31-32), in the translation process, based on which the translation producer selects events/entities, configures their relations, and chooses a monitoring or managing mode to present a specific element textually. As such, any discursive (as opposed to grammatical) deviation from the source-text situation model in a translation can be construed as a sign of mediation that indicates a certain "ideological act of interpretation" (Fowler 1991: 19) similarly deemed by all parties involved in its production as appropriate, desirable or effective in the socio-cultural context perceived by these parties.

Whilst deviation at the selection stage can be evidenced in the inclusion or exclusion of events/entities in the target text, at the presentation stage the best linguistic tool to account for it, as Fowler (1991: 68-70) suggests, is Halliday's functional model, ${ }^{8}$ in which ideational and interpersonal metafunctions that language performs are "especially valuable" for analysis of "mediation of social relationships and values." Among all linguistic representations of these two meta-functions, transitivity, lexis and modality are most relevant to our current study, especially to our observation of the overt managing in the following section. Transitivity includes the process described by the verb, participants in the process and circumstances associated with the process; lexis represents patterns of extralinguistic experience; whilst modality, realized by finite modal operators (e.g. must be, will be and should have) or modal adjuncts (e.g. usually, probably and always), is "an expression of the speaker's opinion" (Halliday 1994: 89). Sifting through these linguistic features in translation selection and presentation will enable us to identify where and how discursive deviations occur.

In the case of the Harry Wu topic in Living History, the two Chinese versions presumably share the situation model in the source text as their common discursive provenance. But as we have seen in the preliminary observation in Section 2, each of them has demonstrated various deviations, which can be explained as ideology-driven mediation, the interplay between managing and monitoring, at stages of selection and presentation. This will be further expounded in the following section.

\section{Operations and effects of mediation in presenting the Harry $\mathrm{Wu}$ topic in the Chinese versions}

This section attempts to bring our theoretical contemplation of mediation onto an observation of the actual realization of mediation in the translated texts. Our data consist of all mentions relating the topical event in the three texts. For simplicity and clarity, they are put in parallel in the appendix, along with brief explanations of their contribution to the development of the topical event placed in brackets in the column of the source text. Expressions that will be discussed in the ensuing part are underlined, and each mention of the protagonist is highlighted in italics.

Note that our analysis of the Yilin version is carried out on the basis of its comparison with the English source text. This is because, as noted in Section 1, during the editing process of the Yilin version, the China Times version was checked against the English text sentence by sentence and revised accordingly. In this connection, the China Times version was taken as a point of reference, rather than a prototype for revision. 


\subsection{Mediation via the selection of the topical event and the configuration of the situation model at the stage of selection}

Both versions maintain the primary components presented in the source text situation model, i.e., the protagonist, the US, the Chinese government and the women's conference. But the occurrence number of the protagonist is reduced to 9 in the Yilin version, as against 21 in the English text and 20 in the China Times version.

In addition, in the China Times version, all mentions concerning the topical event are selected. Apart from this, the inclusion of “踐踏”(tramping on) in Mention 13 is striking, given its absence in the source text. The added word highlights the negative judgment on the status of the mainland human rights. The deletion of His in Mention 14 conceals the fact that the Californian Congress woman was on Wu's side. In consequence, attacks on the US decision to participate in the conference may appear to be not only from Harry Wu but also from other parties.

The Yilin version, on the other hand, chooses to exclude six mentions (Mentions 2, 7, 8, 9, 14 and 16) completely and another seven (Mentions 1, 3, 4, 10, 12, 13 and 15) partially, which are primarily about the protagonist's political background and the interrelation between the US and the topical event. What are included are those that serve to suggest the lawfulness of the action taken by the Chinese government as in parts of Mentions 3 and 10. Also included are those that alone, or together with the ensuing passages, function to mitigate the significance of the topical event as in Mention 11 and part of Mention 1. Additionally, Mentions 5 and 6 that help create a temporal link between the topical event and the US preparation for the UN women's conference are fully selected. Mention 6 in the source text, along with Mentions 7, 8, and 9, plays a role in accentuating the significance of the topical event. Such a textual function is, however, less prominent in the Yilin version, since the zero translation of its co-texts has reduced its textual connection with the rest of the text.

At the same time, the Yilin version resorts to two added cohesive expressions to repair, so to speak, the textual coherence that is weakened by the exclusions and to manage the logical connection between clauses to project a situation somewhat different from that portrayed in the source text. With the exclusion of the source text concessive clause in Mention 3, the added subordinator “因此” (so) creates a causal relationship between the two remaining clauses. The protagonist's arrest thus turns into a lawful action on the Chinese government's part; whilst with the absence of the source text minor clause, Mention 12 loses its connection with the above sentence. As compensation, the conjunctive adverb, “这时” (at this moment), is included as both a structural and content word. As a structural word, it serves to connect the clause with the above context, maintaining the textual cohesion and making the target text less out of place or strange; as a content word, it carries some sort of implication when denoting the temporal relationship between the US decision to attend the conference and Wu's release.

\subsection{Mediation via managing at the stage of presentation}

Once selected, how these events/entities are presented in the target text becomes significant. At this presentation stage, the overt signs of mediation are exemplified in discursive deviations, which guide the development of the situation in a manner 
different from that in the original. This sub-section is to detail these deviations in terms of transitivity, lexis, and modality. As is discussed above, our focus is on discrepancies that carry ideological implications.

TABLE 2

Discursive deviations at the presentation stage

\begin{tabular}{|c|c|c|}
\hline Linguistic rep. $\quad$ Deviation & China Times version & Yilin version \\
\hline Transitivity & 4 & 0 \\
\hline Lexis & 6 & 2 \\
\hline Modality & 1 & 1 \\
\hline Total & 11 & 3 \\
\hline
\end{tabular}

As can be seen from Table 2, the distinction between the two versions is obvious. Except for one modality and one lexical deviation that are shared by both versions, most deviations at levels of transitivity and lexis are only found in the China Times version.

\subsubsection{Transitivity deviation}

According to Halliday (1994: 109), the concepts of process, participants and circumstances in transitivity are semantic categories which explain how phenomena of the real world are represented as linguistic structures. Hence, any deviations in these aspects demonstrate varied interpretations of the real world.

In the China Times version, four mentions are found to deviate in transitivity: two (Mentions 2 and 7) choose to insert a process that is not found in the English text, one (Mention 3) avoids the process in the source text and one (Mention 8) selects a different linguistic representation rather than the original process, thus altering textual nuances. In the source text, Mention 2 relates the identity of the protagonist in a static manner; whilst the China Times version depicts him dynamically as the patient of a material process “被打為” (be hit as, read: be labeled and prosecuted); additionally, the agent of the action is kept unsaid in the process, probably because it is inferable from the context. Such textual management strengthens the author's (or rather, the target text producer's) ideological stance over Wu's case; in Mention 7 in the China Times version, the inserted mental process introduced by “讓...懷疑” (give reason ... to doubt) specifies the supposed negative effect of the US participation in the women's conference on the release of the protagonist; in Mention 3 in the source text, the material process thrown denotes a momentary action; however, when the version chooses to avoid the mention of the process, the temporal boundary for the protagonist's imprisonment becomes blurred; in Mention 8, the relational process in the source text undergoes materialization in its target text counterpart. The target text material process “陷” (sink) indicates a more dynamic and interdependent relationship between the US and Wu's case, and thus endows the topical event with a more central position.

\subsubsection{Lexical deviation}

Another notable device of mediation in terms of managing is the replacement of the original words/phrases with expressions carrying different connotations. In 
Mention 6, the use of the verbal group be thrown into limbo seems to accentuate the effect of Wu's case in the source text. Its textual function decreases when it is replaced with “顯得浮動不安” (seems to be floating restlessly) in the China Times version; and increases when it is translated into “被抛到了脑后” (be put out of mind) in the Yilin version, although the strengthened textual function is not brought into play due to the reason we have discussed in Section 4.1.

Apart from this, in the Yilin version, the replacement of thrown with “拘押” (detained) in Mention 3, which makes the arrest sound more official and more of a lawful action; in the China Times version, five more cases of lexical deviation (Mentions 4, 7, 8, 14 and 15) are found. In Mention 4, the source text attribute widely known implies a wide publicity of Wu's case; whilst its corresponding part, “家喻戶 曉” (become a household name), plays up the influence of the protagonist's case, giving the topical event a more prominent place in the US diplomatic policy; in Mention 7, the source text modifier confused sounds neutral, whereas the corresponding expression “錯誤” (wrong) commits the text to an explicit judgment; a similar case can be found in translating the word confront in Mention 15 as “質疑” (to question [the validity/legality, etc.]); in Mention 8, compared with its original part linked, the selection of “扣在一起” (be interlocked) in the translation tightens up the connection. In Mention 14, the source text attribute coup suggests that the US participation was a turnaround for the Chinese publications; whereas its Chinese translation “晴天霹 靂” ( $a$ bolt from the blue), often collocated with unpleasant events, implies that my presence is a situation of extreme unexpectedness to the Chinese public relations.

\subsubsection{Modality deviation}

As a cover term, modality expresses probability and usuality, indicating the speaker's opinion. In this sense, when the source text modal verb is replaced by a different one in the target text, the degree of the probability or usuality will be changed, which will, in turn, reflect different ideological orientation.

In Mention 1, the use of the finite modal operator might have and the modal adjunct scant in the source text, along with modal adjuncts not unusual, illustrates that the possibility for the topical event to receive attention in the American media is slight, since the arrest of a dissident is not uncommon in mainland China. Yet, their corresponding parts in the China Times version, “可能沒有” (might not have), reduce such a possibility to almost nil. Negativity as such, together with “並不稀奇” (not rare and strange), the counterpart of not unusual, accentuates the prevalence of the arrest of a dissident, and thus suggests a less favourable situation of human rights in the Chinese mainland; on the contrary, their translations in the Yilin version, “原 本不会...太多” (would not have...too much) indicate that it is normal for Wu's arrest to be left unnoticed in the American media. The importance of Wu's case is, therefore, downplayed.

\subsection{The mediated discursive worlds projected in the two translations}

In the China Times version, the effects of the target text producer's mediation in translation are three-fold:

(1) giving more prominence to the topical event and its connection with the US diplomacy (Mentions 4, 7, and 8); 
(2) foregrounding the status of human rights in China by adding a derogative expression (Mention 13), changing modal operators (Mention 1) and inserting a material process that foregrounds the topic as a political prisoner (Mention 2);

(3) reinforcing the author's negative attitude towards the Chinese government by making lexical changes (Mentions 7 and 14).

As a result, the translation presents a discursive world with a more conspicuous ideological commitment. By comparison, the publisher's mediation in the Yilin version is mainly seen in

(1) deemphasizing the significance of the topical event by decreasing its occurrence frequency, modifying the author's attitude over Wu's case (Mention 1) and excluding the relevant knowledge of Wu's political background and his connection with the US diplomacy;

(2) emphasizing the authority of the Chinese government over Wu's case by deselecting derogative expressions about the Chinese government and making a lexical change (Mentions 3 and 10);

(3) creating a seemingly unmediated account of the topical event by adding two cohesive expressions (Mentions 3 and 12).

The mainland readers are thus given a discursive world where Wu's imprisonment in the Chinese mainland is legitimate, and where the topical event does not weigh much in US-China diplomacy.

\section{Impact factors of mediation in the translation process}

From the social functional point of view, the translation process is largely constrained by the target text recipients and their situation and cultural background. In other words, the recipients' needs as perceived by translation producers play a crucial role in deciding how and to what extent the translation should be mediated. From this postulate, a further refinement to our understanding of the position of the target text receiver is needed for a more comprehensive account of the mediation action.

According to Müller (2004: 22), there are two groups of recipients that a writer (also a translator as rewriter) in a sociopolitical context should have in mind: the 'professional' readers involved in the censoring process and the intended reading public. The professional readers refer to censors with "formal qualifications," "work experience" or expertise in their field (Müller 2004: 22-23). They are stereotyped by the government/government agencies and are endowed with privileges in accessing and inspecting the translation before/after publication and in imposing and enforcing constraints on the reading public's access to the book by facilitating or hindering its publication. Their censorship ${ }^{9}$ is practised in accordance with the ideology and the power order that the authority wants to maintain, or in other words, the "wide national patterns of taste" (Billiani 2007: 15) embodied in various laws and regularities. Any contents contravening these laws should be "explicitly prohibited" (Bourdieu 1991: 138). Censorship, in this sense, becomes "an authoritarian control over what reaches the public sphere" (Müller 2004: 12) and a type of power for "establishing a given cultural authority [...] by exercising the power of punishment and the right of surveillance" (Billiani 2007: 15). Compared with the professional readers, the reading public are relatively passive in the sense that they can only read those censored translations and have, by and large, no access to the censored message. As the 
dominant market/cultural force, they are more concerned with the readability of the translation.

In the Chinese mainland, the professional readers are represented by a three-level censorship network including the publisher, provincial Bureau of Press and Publishing Bureau, and the General Administration of Press and Publishing, operating under the Regulations on the Administration of Publishing ${ }^{10}$ and Notice Regarding Further Strengthening the Administration of Censoring Books. ${ }^{10}$ The network is established to ensure that no publications should contain contents against the basic principles confirmed in the Constitution or harmful to security or interests of the country. An interesting example of the way the censorship policy works in translation publishing is provided in Chang (1998). Chang's Chinese translation of Yes Prime Minister was rejected by about ten mainland publishers in the year of 1990. This is because his translation, as Chang (1998: 255) acknowledges, functions as "a form of ideological resistance" and a "political satire," touching upon the "dangerous and often forbidden ground" (Chang 1998: 251), such as sex, anti-communist and anti-Chinese sentiments, in the field of literary translation in the Chinese mainland. In Taiwan, on the other hand, the role of the professional readers is played by Government Information Office, Republic of China as well as the police. Publications are rated in accordance with classification rules ${ }^{11}$ and shall not be against laws. In this connection, the published translation can be viewed as, in Bourdieu's (1991: 137) words, a "compromise" between the author's "expressive interest" and the "censorship."

Different needs of the target text readers pose challenges to the translation producer, who must, on the one hand, keep the translation politically and ideologically consistent with the taste of the professional readers, and on the other, make the translation interesting enough to attract the reading public. These challenges become more serious when there is a political, ideological or cultural conflict between the social and cultural societies the source and the target texts respectively belong to, and when the conflict results in a number of textual inconsistencies with conventional linguistic norms of the target society. It is at this juncture that the "internalized [...] forms of perception and expression" (Bourdieu 1991: 138) of the translation producer, the publisher in the case of Living History, start to work. To put it simply, in order to comply with the professional readers' desires, the translation producer practises self-censorship by mediating the translation process, i.e., by including/ excluding/revising expressions that touch upon the forbidden ground, prior to the official censorship. It is through such coordination between the professional readers and the translation producer that a broad ideological and cultural consensus can be molded in the target society.

\section{Discussion}

Before examining mediation in the translation process, let us take another look at the source text, which was once viewed as "heavily politically invested" by more than half of its American readers. ${ }^{12}$ The inclusion of Harry Wu as a topical subject itself can be taken as a classic case laden with ideological and political information. The presentation of Wu's story, in particular, demonstrates the author's strong concern with the protagonist and her negative stance over China's human rights situation. Nevertheless, as a bestseller, the English text was predicted to have great potential to 
satisfy the Chinese reading public's curiosity about the inside stories of the Clintons and so its translation would have brought about substantial profits. ${ }^{13}$ Yet, to get published, the target text should, first of all, satisfy the professional readers' curiosity, or address their possible concerns.

In general, the ideological and political information carried in the source text conforms to the Taiwan censorial system, and Taiwan society that shares similar political and ideological interests with American society. This can be verified by the fact that most contents about the topic are included in the China Times version. The constant tendency of elevating the significance of the topical event and strengthening the author's negative attitude toward the Chinese mainland revealed in mediation at both translation stages also evidences ideological opposition between the two Chinese societies. The publication of the China Times version proved that these reinforced ideological implications served the Taiwan professional readers. Also, they did not provoke hostile reactions from the author and the American publisher.

By contrast, in the Chinese mainland, the venue of the topical event depicted in the text, the situation is complicated, and all the more complicated because the Harry $\mathrm{Wu}$ topic is politically sensitive and has been banned from the media. In other words, the author's expressive interest in the protagonist does not fit in with the mainland censorial system. Hence, in theory, the publisher should mediate the editing process in order that the mediated version can avoid the "dangerous and often forbidden ground" (Chang 1998: 251) and maintain an ideological coherence with the mainland professional readers. In practice, instead of wiping out all accounts of the topical event, Yilin chose to include the Harry Wu topic, but "make some revisions and a few technical changes whilst keeping the integrity of the book."

At the selection stage, the exclusion of more than half mentions that are primarily about Wu's political experiences and the significance of his case in US-China diplomacy suggests the impact of the mainland censorial system on the translation producer. A knock-on effect is the inclusion of two cohesive expressions in Mentions 3 and 12 , which, on the other hand, bespeaks the translation producers' efforts to cater to the intended reading public. Another salient example is the modality deviation at the presentation stage, which registers a different tone from the source text in presenting the topical event. After being mediated as such, the ideological stance of the author over the Chinese government and the topical event is somewhat neutralized. The compromise achieved between the author's expressive interest and the censorship was approved by the mainland professional readers and finally led to the publication of the translation, an operation that was, however, viewed by the author and the American publisher with bitter resentment.

Apart from this, it is worth noting that some deviations may seem to be inconsistent with the overall ideological tendency as seen in the related operations of mediation. Two explanations suggest themselves in this connection: firstly, deviation may not always be prompted by a conscious, ideologically coherent intention of mediation; secondly, deviation may be caused by different interpretations of the source text. The translation of the phrase be thrown into limbo in Mention 6 is a case in point. In the China Times version, it is given as “顯得浮動不安” (seems to be floating restlessly, a state of uncertainty between two courses of action) obviously following the extended usage of limbo in its first sense, i.e., "a region supposed to exist on the border of Hell as the abode of the just who died before Christ's coming, 
and of unbaptized infants"; ${ }^{14}$ whilst in the Yilin version, contrary to its overall ideological drift, the impact of Harry Wu's case sounds graver as if it were threatening to push those sessions with representatives from the United Nations and other countries out of the minds of those concerned - “被抛到了脑后” (be put out of mind), a translation more in keeping with the figurative meaning of limbo, that is, "any unfavourable place or condition, likened to Limbo; esp. a condition of neglect or oblivion to which persons or things are consigned when regarded as outworn, useless, or absurd." 14

Since mediation is found in both translations and the ideological implications of the source text have been modified accordingly, albeit to differing degrees, the conventionally held concept of faithfulness of the target text to its source text cannot be a real issue in this case. As our investigation suggests, what makes the difference between the two Chinese versions, instead, is in whose interest discursive mediation has been performed. And it is the divided ideological and political "loyalty" (Nord 2001: 123) displayed in the translation producer's mediation and the discursive worlds the resultant texts project that give rise to the different responses from the American author and publisher to the two Chinese versions. Whilst their acceptance of the China Times version indicates their identification with the ideological and political interests of Taiwan society, their criticism of the Yilin version has the mainland professional readers, the censorial system and the dominant ideology and political power they represent, as its true, or ultimate, target.

\section{Concluding remarks}

The present study investigates the textual operation of mediation in translation and its relationship with the socio-cultural context where the target text is supposed to be consumed. Inspirations from Text Linguistics and Halliday's functional model enable us to examine how mediation is realized by means of inclusion and exclusion of information at the selection stage and, at the presentation stage, by means of discursive deviations at levels of transitivity, lexis, and modality. The detailed textual analysis helps delineate a scenario of how the translation is oriented, in a manner favorable to the target text producer's goals, to project a discursive world, differing from that presented in the source text. Concepts from skopos theory and CDA provide insights in discussing the effect of mediation in relation to the target text recipients, i.e., the professional readers and the intended reading public, and their socio-cultural backgrounds. Our discussion shows that for the target text producers whose translation is under constraints of readers' needs, mediation is a powerful means to make the translation commensurate with the ideological interests of the professional readers, i.e., the representatives of the dominant social power. Mediation action itself embodies the power control of the professional readers over the reading public in the target society. Our argument in this article is that an investigation of translation from the perspective of mediation helps reveal the power struggle underlying the translation process. The detailed description of the textual realization of mediation, in particular, helps create an awareness of various ways the target text producers mediate the translation process step by step to achieve the compromise between the author's interests and the professional readers' political concerns so as to get their translation published. 
The present study represents our initial effort to analyze the textual actualization of mediation in translation and to discuss how mediation functions to interact with socio-cultural institutions that may have an impact on the final product of the translation by drawing and integrating concepts from various disciplines. Much more effort is needed to depict the analytical model in greater detail so as to facilitate exploration of translation from such a perspective.

\section{ACKNOWLEDGMENTS}

The authors wish to thank Dr. Robert Neather for his valuable comments on an earlier draft of the study.

\section{NOTES}

1. Clinton, Hillary R. (2003a): Living History. New York: Simon \& Schuster.

2. Clinton, Hillary R. (2003b): 活出歷史 (Live out/through history). (Translated by Yujue Zhong, Weiming YANG \& Xun PAN, et al.) Taipei: China Times.

3. Clinton, Hillary R. (2003c): 亲历历史 (First-hand experience of history). (Translated by Yujue Zhong, Weiming YAng \& Xun PAN, et al.) Nanjing: Yilin Press.

4. Simon \& Schuster (2003): Press Release. Visited September 25 $5^{\text {th }}, 2003$, $<$ http://www.simonsays. com/bookextras/LivingHistory.cfm $>$ (closed site). Also seen in "Publishers Protest China's Censorship of Clinton Book" (Updated last: September 26 ${ }^{\text {th }}$, 2003). Visited October $30^{\text {th }}, 2009$, $<$ http://community.seattletimes.nwsource.com/archive/?date=20030926\&slug=hillary26 $>$.

5. LiU, Feng (January $\left.9^{\text {th }}, 2006\right)$ : personal communication.

6. The "initiator," according to Nord (2001: 20), is the person, group or institution that starts off the translation process and determines its course by defining the purpose for which the target text is needed. In the present case, it is stereotyped by the publisher, i.e., China Times in Taiwan and Yilin in the Chinese mainland.

7. CHen, Junbin (March 26 $\left.6^{\text {th }}, 2007\right)$ : personal communication.

8. Halliday's functional model: the model involves detailed and systematic analyses of three interconnected strands of meaning in a text. These three strands, called "metafunctions" (Halliday 1994), are the ideational, the interpersonal and the textual, which are linked to different linguistic or lexicogrammatical realizations in a text. The major lexicogrammatical realizations of ideational function are the transitivity system and lexis; the interpersonal function by modality; and the textual function by thematic structure, information structure and various patterns of cohesion.

9. According to Billiani (2007: 3-4), "censorship is a form of manipulative rewriting of discourses by one agent or structure over another agent or structure, aiming at filtering the stream of information from one source to another, [...] Primarily it aims to guide the coming into being of forms of aesthetic, ideological and cultural communication. [...] censorship operates largely according to sets of specific values and criteria which are established by a dominant body over a dominated one."

10. In Regulations on the Administration of Publishing issued by the State Council on December $25^{\text {th }}$, 2001, it is stipulated that all publishing businesses shall adhere to the path of serving the people and serving socialism and the guidance of Marxism, Leninism, Mao Zedong Thought and Deng Xiaoping Theory. In 1994, the General Administration of Press and Publishing issued an official document, Notice Regarding Strengthening the Administration of Censoring Books, which was replaced by Notice Regarding Further Strengthening the Administration of Censoring Books in 2004. The document stresses the significance of reinforcing the censorship practice in guaranteeing the adherence of the publishing houses and their employees to the guiding status of Marxism in the ideological field. Under the instruction of these two documents, a three-level censorship network (including the publisher, provincial Bureau of Press and Publishing, and the General Administration of Press and Publishing) is established with a view to monitoring the political, ideological, moral, legal, and policy consequences of the publications on society.

11. For further details, see Government Information Office, Republic of China (Updated last: April 1 $1^{\text {st }}$, 2005): 出版品及錄影節目帶分級辦法 (Regulations Governing the Classification of Publications and Broadcasting Videos). Visited June $12^{\text {th }}, 2007,<$ http://info.gio.gov.tw/ct.asp?xItem=18470\&ct Node $=3454>$. 
12. Anonymous (Updated last: June 16 ${ }^{\text {th }}, 2003$ ): “半数美民众觉得希拉荵回忆录政治意味浓厚 (Half Americans View Hillary’s Memoir Heavily Politically Invested).” Visited April $20^{\text {th }}, 2006,<$ http:// big5.phoenixtv.com:82/gate/big5/www.phoenixtv.com/home/zhuanti/xwshj/xllhyljx/xllhyljx02/200306/16/74990.html>.

13. Z HAO, Chenyu (Updated last: September 24 th, 2003 ): “希拉里自传版权引进的 “秘密武器” 访译林出版社社长章祖德 (The “Secret Weapon” in Copyright Importation of Hillary's Memoir: an Interview with Zude Zhang, the Head of the Yilin Press)." Visited April 4 ${ }^{\text {th }}, 2006,<\mathrm{http}: / /$ news. xinhuanet.com/book/2003-09/24/content_1097133.htm>.

14. Oxford English Dictionary (1989) Oxford University Press: Oxford. Visited September $12^{\text {th }}, 2007$, $<$ http://0-dictionary.oed.com.lib.cityu.edu.hk $>$.

\section{REFERENCES}

BeAugrande, Robert de and Dressler, Wolfgang (1981): Introduction to Text Linguistics. London: Longman.

Billiani, Francesca (2007): Modes of Censorship and Translation: National Contexts and Diverse Media. Manchester: St. Jerome Publishing.

Bourdieu, Pierre (1991): Language and Symbolic Power. (Translated by Gino RAymond and Matthew Adamson) Cambridge: Polity Press, 137-159.

Chang, Namfung (1998): Politics and Poetics in Translation: Accounting for a Chinese Version of 'Yes Prime Minister.' The Translator. 4(2):249-272.

Fairclough, Norman (2003): Analyzing Discourse: Textual Analysis for Social Research. London: Routledge.

FAwCETt, Peter (1995): Translation and Power. The Translator. 1(2):177-192.

Foucault, Michael (1984): The Order of Discourse. In: Michael J. Shapiro, ed. Language and Politics. New York: New York University Press, 108-138.

Fowler, Roger (1991): Language in the News: Discourse and Ideology in the Press. London: Routledge.

Halliday, Michael A.K. (1994): An Introduction to Functional Grammar. London: Edward Arnold.

Iser, Wolfgang (2006): How to Do Theory. Malden (MA): Blackwell Pub.

Müller, Beate, ed. (2004): Censorship \& Cultural Regulation in the Modern Age. Amsterdam: Rodopi.

Nord, Christiane (2001): Translating as a Purposeful Activity: Functionalist Approaches Explained. Shanghai: Shanghai Foreign Language Education Press.

Shäffner, Christina (2001): Skopos Theory. In: Mona BAKer, ed. Routledge Encyclopedia of Translation Studies. Shanghai: Shanghai Foreign Language Education Press, 235-238.

WodAk, Ruth and Meyer, Michael, eds. (2001): Methods of Critical Discourse Analysis. London: Sage.

\section{APPENDIX}

\begin{tabular}{|c|c|c|c|}
\hline Mention & Source Text & $\begin{array}{l}\text { China Times version } \\
\text { and back translation }\end{array}$ & $\begin{array}{l}\text { Yilin version } \\
\text { and back translation }\end{array}$ \\
\hline 1 & $\begin{array}{l}\text { The arrest of a dissident } \\
\text { is not unusual in China, } \\
\text { and Harry Wu's } \\
\text { imprisonment might } \\
\text { have received scant } \\
\text { attention in the } \\
\text { American media. } \\
\text { (p. 298) } \\
\text { [setting the tone for } \\
\text { Wu's case] }\end{array}$ & $\begin{array}{l}\text { 異議人士被捕在中國大陸並不 } \\
\text { 稀奇, 而吳弘達入獄的消息可 } \\
\text { 能沒有受到美國媒體的注意。 } \\
\text { (p. 321) } \\
\text { The arrest of dissidents in the } \\
\text { Chinese mainland is not rare } \\
\text { and strange, yet Wu Hongda’s } \\
\text { imprisonment might have not } \\
\text { attract any attention in the } \\
\text { American media. }\end{array}$ & $\begin{array}{l}\text { 吴弘达被捕的消息原 } \\
\text { 本不会受到美国媒体 } \\
\text { 的太多关注。(p. 263) } \\
\text { Wu Hongda's arrest } \\
\text { would not have } \\
\text { received too much } \\
\text { attention in the } \\
\text { American media. }\end{array}$ \\
\hline
\end{tabular}




\begin{tabular}{|c|c|c|c|}
\hline 2 & $\begin{array}{l}\text { Wu, a human rights } \\
\text { activist who had spent } \\
\text { nineteen years as a } \\
\text { political prisoner in } \\
\text { Chinese labor camps } \\
\text { before emigrating to the } \\
\text { United States, was } \\
\text { arrested by Chinese } \\
\text { authorities on June 19, } \\
1995, \text { as he entered } \\
\text { Xinjiang Province from } \\
\text { neighboring } \\
\text { Kazakhstan. (p. 298) } \\
\text { [introducing Wu's } \\
\text { political background] }\end{array}$ & $\begin{array}{l}\text { 吳弘達是人權活躍份子, 被打 } \\
\text { 為政治犯, 在中國勞改營待了十 } \\
\text { 九年, 然後移居美國, 一九九五 } \\
\text { 年六月十九日從哈薩克進入新 } \\
\text { 疆時, 被中國當局逮捕。(p. 321) } \\
\text { Wu Hongda was a human } \\
\text { rights activist, [and] was } \text { was } \\
\text { labeled and prosecuted as a } \\
\text { political prisoner, [and] had } \\
\text { stayed in Chinese labor camps } \\
\text { for } 19 \text { years, before emigrating } \\
\text { to the United States; on June 19, } \\
1995 \text { when [he] entered } \\
\text { Xinjiang from Kazakhstan, [he] } \\
\text { was arrested by the Chinese } \\
\text { authorities. }\end{array}$ & $\begin{array}{l}\text { [No translation } \\
\text { (should have been } \\
\text { p. 263)] }\end{array}$ \\
\hline 3 & $\begin{array}{l}\text { Although he had a valid } \\
\text { visa to visit China, he } \\
\text { was charged with } \\
\text { espionage and thrown in } \\
\text { jail to await trial. } \\
\text { (p. 298) } \\
\text { [specifying Wu's second } \\
\text { jail experience] }\end{array}$ & $\begin{array}{l}\text { 雖然他有入境中國的有效簽 } \\
\text { 證, 但被控從事間諜活動, 在獄 } \\
\text { 中等待審判。(p. 321) } \\
\text { Although he had a valid visa to } \\
\text { enter China, [he] was charged } \\
\text { with espionage and was in jail } \\
\text { waiting for trial. }\end{array}$ & $\begin{array}{l}\text { 吴弘达被控从事间谍 } \\
\text { 活动, 因此被拘押并 } \\
\text { 等待审判。(p. 263) } \\
\text { Wu Hongda was } \\
\text { charged with espio- } \\
\text { nage, so [he] was } \\
\text { detained, waiting for } \\
\text { trial. }\end{array}$ \\
\hline 4 & $\begin{array}{l}\text { Overnight, } \underline{\text { Harry Wu }} \\
\text { became widely known, } \\
\text { and U.S. participation in } \\
\text { the women's conference } \\
\text { was cast into doubt as } \\
\text { human rights groups, } \\
\text { Chinese American } \\
\text { activists and some } \\
\text { members of Congress } \\
\text { urged our nations to } \\
\text { boycott. (p. 298) } \\
\text { [strengthening the effect } \\
\text { of Wu's case] }\end{array}$ & $\begin{array}{l}\text { 吳弘達在一夕之間家喻戶曉, 由 } \\
\text { 於人權團體、華裔美籍活躍人 } \\
\text { 士和一些美國國會議員呼籥美 } \\
\text { 國抵制聯合國第四屆婦女大 } 大 \\
\text { 會, 為美國是否與會投下變數。 } \\
\text { (p. 323) } \\
\text { Wu Hongda overnight became a } \\
\text { household name, and human } \\
\text { rights groups, Chinese } \\
\text { American activists and some } \\
\text { members of Congress urged the } \\
\text { U.S. to boycott the United } \\
\text { Nations Fourth World } \\
\text { Conference, which made the U. } \\
\text { S. participation in the confer- } \\
\text { ence uncertain. }\end{array}$ & $\begin{array}{l}\text { 由于各种团体和一些 } \\
\text { 美国国会议员呼吁美 } \\
\text { 国抵制联合国第四届 } \\
\text { 妇女大会, 美国是否与 } \\
\text { 会变得不确定起来。 } \\
\text { (p. 263) } \\
\text { As various groups and } \\
\text { some members of } \\
\text { Congress urged the U. } \\
\text { S. to boycott the } \\
\text { United Nations Fourth } \\
\text { World Conference, } \\
\text { whether the U.S. would } \\
\text { participate in the } \\
\text { conference became } \\
\text { uncertain. }\end{array}$ \\
\hline 5 & $\begin{array}{l}\text { At the time of Harry } \\
\text { Wu's arrest, my staff and } \\
\text { I were deeply involved in } \\
\text { planning for the } \\
\text { conference. (p. 299) } \\
\text { [creating a synchronic } \\
\text { connection between } \\
\text { Wu's case and the } \\
\text { conference] }\end{array}$ & $\begin{array}{l}\text { 吳弘達被捕時, 我的幕僚和我 } \\
\text { 都在積極規計參加這次大會。( } \\
\text { p. 322) } \\
\text { When Wu Hongda was } \\
\text { arrested, my staff and I were } \\
\text { actively planning for the } \\
\text { conference. }\end{array}$ & $\begin{array}{l}\text { 吴弘达被捕时, 我的幕 } \\
\text { 僚和我都在积极计划 } \\
\text { 参加这次大会。 } \\
\text { (p. 264) } \\
\text { When Wu Hongda was } \\
\text { arrested, my staff and I } \\
\text { were actively planning } \\
\text { for the conference. }\end{array}$ \\
\hline
\end{tabular}




\begin{tabular}{|c|c|c|c|}
\hline 6 & $\begin{array}{l}\text { Months of meetings and } \\
\text { strategy sessions with } \\
\text { representatives from the } \\
\text { United Nations and } \\
\text { other countries were } \\
\text { thrown into limbo after } \\
\text { Wu's imprisonment. } \\
\text { (p. } 300 \text { ) } \\
\text { [accentuating the effect } \\
\text { of Wu's case over } \\
\text { meetings with represen- } \\
\text { tatives from UN and } \\
\text { other countries] }\end{array}$ & $\begin{array}{l}\text { 幾個月來與來自聯合國以及其 } \\
\text { 他國家的代表召開的會議, 在 } \\
\text { 吳弘達被拘押後顯得浮動不 } \\
\text { 安。(p. 323) } \\
\text { Months of meetings with } \\
\text { representatives from the United } \\
\text { Nations and other countries } \\
\text { seem to be floating restlessly } \\
\text { after Wu Hongda's imprison- } \\
\text { ment. }\end{array}$ & $\begin{array}{l}\text { 几个月来与来自联合国 } \\
\text { 以及其它国家的代表 } \\
\text { 召开的会议在吴弘达 } \\
\text { 被拘押后被拋到了脑 } \\
\text { 后。(p. 264) } \\
\text { Months of meetings } \\
\text { with representatives } \\
\text { from the United } \\
\text { Nations and other } \\
\text { countries were put out } \\
\text { of mind after Wu } \\
\underline{\text { Hongda's imprison- }} \\
\text { ment. }\end{array}$ \\
\hline 7 & $\begin{array}{l}\text { I was particularly } \\
\text { troubled by a personal } \\
\text { letter from Mrs. Wu, } \\
\text { who was understandably } \\
\text { worried about her } \\
\text { husband's fate and felt } \\
\text { that my participation in } \\
\text { the conference "would be } \\
\text { sending a confused } \\
\text { signal to the leaders in } \\
\text { Beijing about the resolve } \\
\text { of the U.S. to press for } \\
\text { Harry's release." (p. 300) } \\
\text { [leading to the relation- } \\
\text { ship between the topical } \\
\text { event and the US] }\end{array}$ & 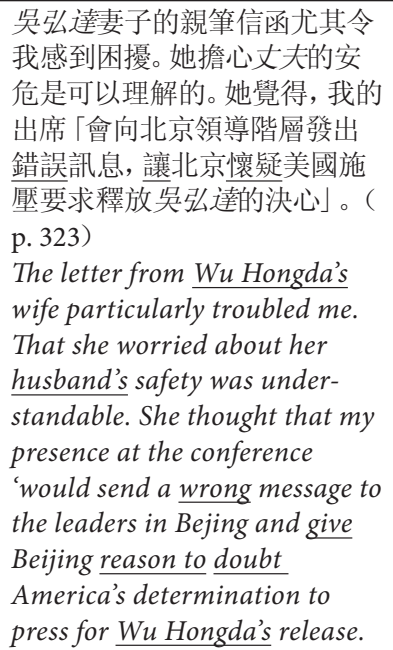 & $\begin{array}{l}\text { [No translation } \\
\text { (should have been } \\
\text { p. 264)] }\end{array}$ \\
\hline 8 & $\begin{array}{l}\text { We were in a diplomatic } \\
\text { bind in which Harry } \\
\text { Wu's imprisonment and } \\
\text { my attendance at the } \\
\text { conference were linked. } \\
\text { (p. } 300 \text { ) } \\
\text { [establishing a close } \\
\text { relationship between the } \\
\text { topical event and the } \\
\text { US] }\end{array}$ & $\begin{array}{l}\text { 我們陷入一種外交牽制, 吳弘 } \\
\text { 達被的和我出席婦女大會扣在 } \\
\text { 一起。(p. 323) } \\
\text { We sank into a diplomatic bind, } \\
\text { Wu Hongda's imprisonment } \\
\text { and my attendance at the } \\
\text { women's conference were now_ } \\
\text { interlocked. }\end{array}$ & $\begin{array}{l}\text { [No translation } \\
\text { (should have been } \\
\text { p. 264)] }\end{array}$ \\
\hline 9 & $\begin{array}{l}\text { Our government } \\
\text { continued to state } \\
\text { privately and publicly } \\
\text { that I would not attend } \\
\text { if Mr. Wu remained } \\
\text { under arrest. (p. } 300) \\
\text { [explicating the } \\
\text { relationship] }\end{array}$ & $\begin{array}{l}\text { 美國政府在私下和公開場合一 } \\
\text { 再表示, 只要吳弘達被羈押, 我 } \\
\text { 就不會出席。(p. } 323 \text { ) } \\
\text { The US government on private } \\
\text { and public occasions repeatedly } \\
\text { stated that if Wu Hongda } \\
\text { remained imprisoned, I would } \\
\text { not attend the conference. }\end{array}$ & $\begin{array}{l}\text { [No translation } \\
\text { (should have been } \\
\text { p. 264)] }\end{array}$ \\
\hline
\end{tabular}




\begin{tabular}{|c|c|c|c|}
\hline 10 & $\begin{array}{l}\text { Less than a month before } \\
\text { the start of the confer- } \\
\text { ence, the Chinese } \\
\text { government evidently } \\
\text { decided that it couldn't } \\
\text { afford to generate more } \\
\text { bad publicity. In a sham } \\
\text { trial in Wuhan on } \\
\text { August 24, a Chinese } \\
\text { court convicted Harry } \\
\text { Wu of spying and } \\
\text { expelled him from the } \\
\text { country. (p. 300) } \\
\text { [detailing the interrela- } \\
\text { tion between the topic } \\
\text { and the Chinese } \\
\text { background, the impact } \\
\text { of the topical event on } \\
\text { the background } \\
\text { situation] }\end{array}$ & $\begin{array}{l}\text { 距離大會揭幕不到一個月的時 } \\
\text { 間, 中國政府顯然認定中國不 } \\
\text { 能再承受不利的宣傳, 於是法 } \\
\text { 院在八月二十四日裝模作樣審 } \\
\text { 判吳弘達, 最後判決他從事間 } \\
\text { 諜活動, 將他驅逐出境。( } \\
\text { p. 323) } \\
\text { Less than a month before the } \\
\text { conference, the Chinese } \\
\text { government obviously held that } \\
\text { China could not bear disadvan- } \\
\text { tageous propaganda, so a court } \\
\text { pretentiously put Wu Hongda } \\
\text { on trial on August } 24 \text { and } \\
\text { finally convicted him of spying } \\
\text { and expelled him from the } \\
\text { country. }\end{array}$ & $\begin{array}{l}\text { 中国判决吴弘达从事 } \\
\text { 间谍活动, 将他驱逐 } \\
\text { 出境。(p. 264) } \\
\text { China convicted } \underline{W u} \\
\text { Hongda of spying and } \\
\text { expelled him from the } \\
\text { country. }\end{array}$ \\
\hline 11 & $\begin{array}{l}\text { Some media commenta- } \\
\text { tors, and Wu himself, } \\
\text { were convinced that the } \\
\text { United States had made } \\
\text { a political deal with the } \\
\text { Chinese: } \text { Wu would be } \\
\text { released, but only if I } \\
\text { agreed to come to the } \\
\text { conference and refrain } \\
\text { from critical remarks } \\
\text { about the host govern- } \\
\text { ment. (p. } 300 \text { ) } \\
\text { [relating the develop- } \\
\text { ment of the interrela- } \\
\text { tion, and the extent and } \\
\text { intensity of its impact } \\
\text { that is denied by the } \\
\text { author in the following } \\
\text { part] }\end{array}$ & $\begin{array}{l}\text { 有些媒體評論家以及吳本人都 } \\
\text { 相信, 美、中已經達成政治交 } \\
\text { 易: 吳獲釋, 但前提是我出席 } \\
\text { 婦女大會以及不發表批評地主 } \\
\text { 國政府的言論。(p. 323) } \\
\text { Some media commentators and } \\
\text { Wu himself all believed that the } \\
\text { US and China had made a } \\
\text { political deal: Wu would be } \\
\text { released, but on the premise } \\
\text { that I attended the women's } \\
\text { conference and did not make } \\
\text { critical remarks about the host } \\
\text { government. }\end{array}$ & $\begin{array}{l}\text { 一些媒体评论家以及 } \\
\text { 吴本人都相信, 美中已 } \\
\text { 经达成政治交易: 吴 } \\
\text { 获释, 但前提是我出席 } \\
\text { 妇女大会以及不发表 } \\
\text { 批评东道主国政府的 } \\
\text { 言论。(p. 264) } \\
\text { Some media commen- } \\
\text { tators and Wu himself } \\
\text { all believed that the US } \\
\text { and China had made a } \\
\text { political deal: Wu } \\
\text { would be released, but } \\
\text { on the premise that I } \\
\text { attended the women's } \\
\text { conference and did not } \\
\text { make critical remarks } \\
\text { about the host } \\
\text { government. }\end{array}$ \\
\hline 12 & $\begin{array}{l}\text { Once the Wu case was } \\
\text { resolved, the White } \\
\text { House and State } \\
\text { Department determined } \\
\text { that I should make the } \\
\text { trip. (p. } 301 \text { ) } \\
\text { [specifying the outcome } \\
\text { of the interrelation] }\end{array}$ & $\begin{array}{l}\text { 一旦吳案獲得解決, 白宮和國 } \\
\text { 務院都確定我應該成行。( } \\
\text { p. 323) } \\
\text { Once Wu's case was settled, the } \\
\text { White House and State } \\
\text { Department both determined } \\
\text { that I should make the trip. }\end{array}$ & $\begin{array}{l}\text { 这时, 白宫和国务院都 } \\
\text { 确定我应该成行。 } \\
\text { (p. 264) } \\
\text { At this moment, the } \\
\text { White House and State } \\
\text { Department both } \\
\text { decided that I should } \\
\text { make the trip. }\end{array}$ \\
\hline
\end{tabular}




\begin{tabular}{|c|c|c|c|}
\hline 13 & $\begin{array}{l}\text { Back home in } \\
\text { California, } \text { Mr. Wu } \\
\text { criticized my decision, } \\
\text { reiterating that my } \\
\text { attendance might be } \\
\text { constructed as a tacit } \\
\text { approval of China's } \\
\text { record on human } \\
\text { rights.(p. 301) } \\
\text { [reporting the protago- } \\
\text { nist's objection to the } \\
\text { outcome and its } \\
\text { content] }\end{array}$ & $\begin{array}{l}\text { 吳弘達返回加州寓所後批評我 } \\
\text { 的決定。他重申我的出席可能 } \\
\text { 被解讀為默許中國踐踏人權。 } \\
\text { (p. } 323 \text { ) } \\
\text { Wu Hongda returned his } \\
\text { apartment in California and } \\
\text { criticized my decision. He } \\
\text { reiterated that my attendance } \\
\text { might be interpreted as a tacit } \\
\text { approval of China's tramping } \\
\text { on human rights. }\end{array}$ & $\begin{array}{l}\text { 吴弘达返回加州寓所 } \\
\text { 后批评我的决定。 } \\
\text { (p. 264) } \\
\text { Wu Hongda returned } \\
\text { his apartment in } \\
\text { California and } \\
\text { criticized my decision. }\end{array}$ \\
\hline 14 & $\begin{array}{l}\text { His Congress woman, } \\
\text { Nancy Pelosi, called to } \\
\text { tell me that my presence } \\
\text { would be a public } \\
\text { relations coup for the } \\
\text { Chinese. (p. } 301 \text { ) } \\
\text { [reporting the objection } \\
\text { from the Congress } \\
\text { woman] }\end{array}$ & $\begin{array}{l}\text { 加州眾議員裴洛西 (Nancy } \\
\text { Pelosi) 女士打電話告訴我， } \\
\text { 我的出席對中國人民的公關行 } \\
\text { 動是晴天霹靂。(p. 323) } \\
\text { [Californian Congress woman, } \\
\text { Nancy Pelosi, called to tell me } \\
\text { that my presence would be a } \\
\text { bombshell to Chinese public } \\
\text { relations] }\end{array}$ & $\begin{array}{l}\text { [No translation } \\
\text { (should have been } \\
\text { p. 264)] }\end{array}$ \\
\hline 15 & $\begin{array}{l}\text { He supported my view } \\
\text { that once Wu had been } \\
\text { released, the best way to } \\
\text { confront the Chinese } \\
\text { about human rights was } \\
\text { directly, on their turf. } \\
\text { (p. } 301 \text { ) } \\
\text { [referring to a support- } \\
\text { ive comment that helps } \\
\text { to transfer the issue } \\
\text { onto a higher, inter- } \\
\text { governmental level] }\end{array}$ & $\begin{array}{l}\text { 他支持我的看法, 一旦吳弘達 } \\
\text { 獲釋, 最好質疑中國其人權紀 } \\
\text { 錄的方法就是直接到他們的領 } \\
\text { 土上。(p. } 224 \text { ) } \\
\text { He supported my view, once Wu } \\
\text { Hongda was released, the best } \\
\text { way to question China's human } \\
\text { rights was directly on their turf. }\end{array}$ & $\begin{array}{l}\text { 比尔支持我的看法。 } \\
\text { (p. 264) } \\
\text { Bill supported my view. }\end{array}$ \\
\hline 16 & $\begin{array}{l}\text { One happy by-product of } \\
\text { the Harry Wu incident } \\
\text { was that it generated } \\
\text { huge publicity for the } \\
\text { UN conference. (p. } 302) \\
\text { [linking the topic back } \\
\text { to the major theme of } \\
\text { the chapter] }\end{array}$ & $\begin{array}{l}\text { 吳弘達事件衍生的一個不錯的 } \\
\text { 結果, 就是這次聯合國婦女大 } \\
\text { 會在媒體的曝光率大增。 } \\
\text { (p. 324) } \\
\text { One good result of the } \underline{\text { Wu }} \\
\text { Hongda incident was that it } \\
\text { hugely increased the publicity } \\
\text { for the UN conference in the } \\
\text { media. }\end{array}$ & $\begin{array}{l}\text { [No translation } \\
\text { (should have been } \\
\text { p. 265)] }\end{array}$ \\
\hline
\end{tabular}

